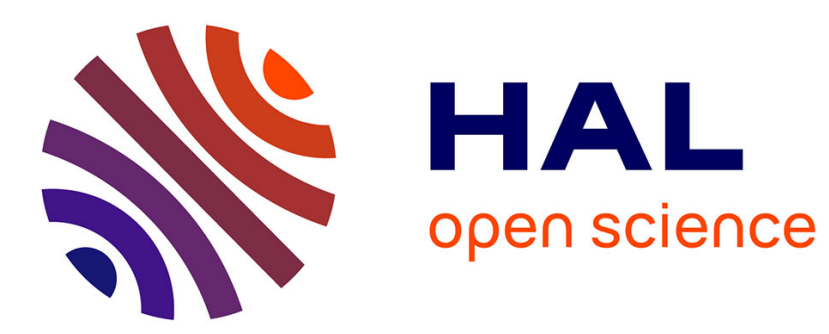

\title{
Function of MRP1 is not dependent on cholesterol or cholesterol-stabilized lipid rafts
}

Peter Meszaros, Karin Klappe, Ina Hummel, Dick Hoekstra, Jan Willem Kok

\section{To cite this version:}

Peter Meszaros, Karin Klappe, Ina Hummel, Dick Hoekstra, Jan Willem Kok. Function of MRP1 is not dependent on cholesterol or cholesterol-stabilized lipid rafts. Biochemical Journal, 2011, 437 (3), pp.483-491. 10.1042/BJ20110427 . hal-00608394

\section{HAL Id: hal-00608394 \\ https://hal.science/hal-00608394}

Submitted on 13 Jul 2011

HAL is a multi-disciplinary open access archive for the deposit and dissemination of scientific research documents, whether they are published or not. The documents may come from teaching and research institutions in France or abroad, or from public or private research centers.
L'archive ouverte pluridisciplinaire $\mathbf{H A L}$, est destinée au dépôt et à la diffusion de documents scientifiques de niveau recherche, publiés ou non, émanant des établissements d'enseignement et de recherche français ou étrangers, des laboratoires publics ou privés. 


\title{
Function of MRP1 is not dependent on cholesterol or cholesterol-stabilized lipid rafts
}

\author{
Peter Meszaros*, Karin Klappe*, Ina Hummel*, Dick Hoekstra and Jan Willem Kok \\ Department of Cell Biology, Section Membrane Cell Biology, \\ University Medical Center Groningen, University of Groningen, \\ A. Deusinglaan 1, 9713 AV Groningen, The Netherlands
}

*The first three authors have contributed equally to this article

Correspondence to: Jan Willem Kok, University Medical Center Groningen, University of Groningen, Department of Cell Biology, Section Membrane Cell Biology, A. Deusinglaan 1, 9713 AV Groningen, The Netherlands, Tel. 31-50-3632725; Fax 31-50-3632728; E-mail: j.w.kok@med.umcg.nl 


\section{Synopsis}

MRP1 ${ }^{*}$ has been localized in cholesterol-enriched lipid rafts, which suggests a role for these lipid rafts and/or cholesterol in MRP1 function. Here we show for the first time that nearly complete oxidation of free cholesterol in the plasma membrane of BHK-MRP1 cells did not affect MRP1 localization in lipid rafts or its efflux function, using 5-carboxyfluorescein diacetate as substrate. Inhibition of cholesterol biosynthesis, using lovastatin in combination with RO 48-8071, resulted in a shift of Mrp1 out of lipid raft fractions, but did not affect Mrp1-mediated efflux in Neuro-2a cells. Short-term methyl- $\beta$-cyclodextrin treatment was equally effective in removing free cholesterol from Neuro-2a and BHK-MRP1 cells, but affected MRP1 function only in the latter. The kinetics of loss of both MRP1/Mrp1 efflux function and lipid raft association during long-term methyl- $\beta$-cyclodextrin treatment did not match the kinetics of free cholesterol removal in both cell lines. Moreover, MRP1 activity was measured in vesicles consisting of membranes isolated from BHK-MRP1 cells using the substrate cysteinyl leukotriene $\mathrm{C}_{4}$ and was not changed when the free cholesterol level of these membranes was either decreased or increased. In conclusion, MRP1/Mrp1 activity is not correlated with the level of free cholesterol or with localization in cholesterol-dependent lipid rafts.

Page heading title: MRP1 ${ }^{\ddagger}$ function is independent of cholesterol

Supplementary Key Words: methyl- $\beta$-cyclodextrin, lovastatin, RO 48-8071, cholesterol oxidase, ATPase activity; $\mathrm{LTC}_{4}$ transport assay

Abbreviations: ABC, ATP-binding cassette; CDC, methyl- $\beta$-cyclodextrin/cholesterol; CFDA, 5-carboxyfluorescein diacetate; $\mathrm{CO}$, cholesterol oxidase; DRM, detergent resistant membrane; LO, lovastatin; $\mathrm{LTC}_{4}$, cysteinyl leukotriene $\mathrm{C}_{4}$; M- $\beta-\mathrm{CD}$ or $\mathrm{CD}$, methyl- $\beta$ cyclodextrin; MRP1, multidrug-resistance-related protein 1; RO, RO 48-8071 


\section{Introduction}

One of the best characterized multidrug resistance mechanisms is the energy-dependent drug efflux by proteins belonging to the ATP-binding cassette $(\mathrm{ABC})$ transporter protein superfamily. Multidrug-resistance-related protein 1 (MRP1) and P-glycoprotein are the most widely studied $\mathrm{ABC}$ transporters and are known to depend on their direct lipid environment for optimal functioning [1,2]. Lavie et al. [3] have shown for the first time the association of an ABC transporter with a membrane domain. They found that a substantial fraction of Pglycoprotein was located in Cav-1 containing Triton X-100-based detergent resistant membranes (DRMs) in P-glycoprotein overexpressing cells. Later studies showed localization of both P-glycoprotein and MRP1 in non-caveolar DRMs. Both ABC transporters were more strongly enriched in Lubrol-based or Brij-based DRMs compared to Triton X-100-based DRMs [4,5].

Given their localization in DRMs, the function of ABC transporters may well be dependent on cholesterol, which is known to be enriched in DRMs. Modulation of Pglycoprotein function by cholesterol and involvement of DRMs in this process are widely studied [6]. For example, cholesterol depletion resulted in a shift of P-glycoprotein out of DRM fractions and P-glycoprotein-mediated drug transport was also affected [7]. In Caco-2 cell monolayers, cholesterol depletion significantly impaired the efflux activity of Pglycoprotein [8]. Concerning modulation of MRP1 function by cholesterol, information is scarce. In one study, cholesterol was reported to modulate MRP1 function and this was related to the presence of MRP1 in DRMs [9]. It is important to rigorously establish whether cholesterol affects MRP1 function, as this could be the underlying mechanism for the appearance of MRP1 in lipid rafts and a potential target for manipulation of MRP1 activity in the context of tumour cell sensitization to cytostatics.

In this study we rigorously investigated the impact of cholesterol and the localization of MRP1/Mrp1 in cholesterol-dependent lipid rafts on efflux function of the ABC transporter in two cell lines. We used Neuro-2a (neuroblastoma) cells, which express endogenous murine Mrp1/Abcc1 and BHK-MRP1 (fibroblast) cells, which highly express stable transfected human MRP1/ABCC1 [10]. In addition, we studied ABCC1 function in vesicles consisting of membranes isolated from cholesterol-modulated BHK-MRP1 cells. In view of potential drawbacks using detergent-based protocols for lipid raft isolation [11,12], we employed the detergent-free lipid raft isolation procedure recently developed by Macdonald and Pike [13]. Various strategies were employed to manipulate cellular cholesterol levels, including 1) shortand long-term methyl- $\beta$-cyclodextrin $(\mathrm{M}-\beta-\mathrm{CD})$ treatment, which physically removes cholesterol from the plasma membranes of cells, 2) cholesterol oxidase treatment, which chemically converts cholesterol into cholestenon and 3) combined treatment with lovastatin, an inhibitor of 3-hydroxy-3methylglutaryl-coenzyme A reductase and RO 48-8071, an inhibitor of oxidosqualene cyclase. Abcc1/ABCC1 activity did not correlate with the variable levels of cholesterol, either in intact cells or isolated membranes. Neither did Abcc1/ABCC1 activity correlate with the protein's variable extent of lipid raft localization resulting from cholesterol modulation. We conclude that Abcc1/ABCC1 function is not dependent on cholesterol or cholesterol-dependent lipid raft localization, while the observed effect of (longterm) $M-\beta-C D$ treatment in intact cells, likely relates to reduced membrane integrity. 


\section{Materials and methods}

Materials

MK571 was a gift from Prof. A.W. Ford-Hutchinson (Merck-Frosst, Inc., Kirkland, Canada). All cell culture plastic was from Costar (Cambridge, MA, USA). Cell culture media, Hank's balanced salt solution (HBSS), antibiotics, L-glutamine, sodium pyruvate and trypsin were purchased from Gibco (Invitrogen, Paisley, UK). Fetal calf serum (FCS) was from Bodinco (Alkmaar, The Netherlands). RO 48-8071 was from Enzo Life Sciences AG (Farmingdale, NY, USA). Cholesterol oxidase was purchased from Calbiochem (Merck KgaA, Darmstadt, Germany). 5-Carboxyfluorescein diacetate (CFDA), cysteinyl leukotriene $\mathrm{C}_{4}$ (LTC4), 3-[4,5dimethylthiazol-2-yl]-2,5-diphenyl tetrazolium bromide (MTT), lovastatin, and methyl- $\beta$ cyclodextrin (M- $\beta-C D)$ were purchased from Sigma-Aldrich (St. Louis, MO, USA). $\left[{ }^{3} \mathrm{H}\right] \mathrm{LTC}_{4}$ was purchased from PerkinElmer (Waltham, MA, USA). Cholesterol was from Avanti Polar Lipids (Alabaster, AL, USA). The rat monoclonal anti-ABCC1 (MRPr1) antibody was obtained from Alexis (Dedham, MD, USA). GF/C short drop filterplates were from Whatman (Kent, UK). OptiPrep was from Axis-Shield PoC AS (Dundee, Scotland).

\section{Cell culture and incubation conditions}

The murine neuroblastoma cell line Neuro-2a was purchased from the ATCC (Manassas, VA, USA). These cells were grown as adherent monolayer cultures in Dulbecco's modified Eagle medium supplemented with $10 \%$ FCS, 100 units $/ \mathrm{ml}$ penicillin, $100 \mu \mathrm{g} / \mathrm{ml}$ streptomycin, 2 $\mathrm{mM}$ L-glutamine and $1 \mathrm{mM}$ sodium pyruvate, under standard incubator conditions (humidified atmosphere, $5 \% \mathrm{CO}_{2}, 37^{\circ} \mathrm{C}$ ). The hamster BHK cell line stably expressing the human $A B C C 1$ gene, named BHK-MRP1, was a gift from Dr. Riordan (Mayo Clinic Arizona, S.C. Johnson Medical Research Center, Scottsdale, AZ, USA; ref. 10). These cells were grown as adherent monolayer cultures in Dulbecco's modified Eagle medium/NUT mix F-12 (1:1) supplemented with $10 \%$ FCS, 100 units $/ \mathrm{ml}$ penicillin, $100 \mu \mathrm{g} / \mathrm{ml}$ streptomycin and 2 $\mathrm{mM}$ L-glutamine, under standard incubator conditions (humidified atmosphere, $5 \% \mathrm{CO}_{2}$, $37^{\circ} \mathrm{C}$ ). The cells were kept under selective pressure by growing them in the presence of 100 $\mu \mathrm{M}$ methotrexate. In order to deplete cholesterol, cells were incubated in the presence of 10 $\mathrm{mM}$ M- $\beta-C D$ for various time intervals in serum-free medium. Alternatively, Neuro-2a cells were incubated for $20 \mathrm{~h}$ in the presence of both $1 \mu \mathrm{M}$ RO 48-8071, an inhibitor of oxidosqualene cyclase, and $1 \mu \mathrm{g} / \mathrm{ml}$ lovastatin, an inhibitor of 3-hydroxy-3methylglutarylcoenzyme A reductase, in serum-free medium. As a control in this case, cells were grown in serum-free medium for $20 \mathrm{~h}$ with vehicle. In order to chemically convert cholesterol to cholestenon, cells were incubated in the presence of $1 \mathrm{U} / \mathrm{ml}$ cholesterol oxidase for $1 \mathrm{~h}$. For cell membrane preparations cells were grown in roller bottles, harvested by trypsinization, and then subjected to cholesterol oxidase or $M-\beta-C D$ treatment for various time intervals to deplete plasma membrane cholesterol. For cholesterol loading of the plasma membrane, M- $\beta$ $\mathrm{CD}$ filled with cholesterol (M- $\beta-\mathrm{CD} /$ cholesterol) was used for different incubation times in serum-free medium at $37{ }^{\circ} \mathrm{C}$ (10 mM concentration). To prepare $\mathrm{M}-\beta-\mathrm{CD} / \mathrm{cholesterol,} 100 \mathrm{mg}$ $\mathrm{M}-\beta-\mathrm{CD}$ was dissolved in $2 \mathrm{ml}$ water and $3 \mathrm{mg}$ cholesterol (solution in ethanol) was added slowly while stirring at $60-70{ }^{\circ} \mathrm{C}$. This was dried and used later as described above. After treatment cells were centrifuged (3000 rpm, $3 \mathrm{~min}$ ), frozen in liquid nitrogen and stored at -80 ${ }^{\circ} \mathrm{C}$ until membrane isolation. Control cells were treated similarly but in the absence of cholesterol modulators, i.e. solvent controlled when applicable.

\section{Isolation of detergent-free lipid rafts}

Detergent-free lipid rafts were isolated as described $[13,14]$. 


\section{Immunoblot analysis}

Protein from equal volumes of the gradient fractions was processed as described [14].

\section{Cholesterol determination}

To quantify free cholesterol, a lipid extraction [15] on cells or pooled detergent-free lipid fractions was performed after a protein determination [16]. The cholesterol concentration was determined spectrophotometrically by a cholesterol oxidase/peroxidase assay [17]. The amount of cholesterol was expressed relative to the protein content.

\section{Sphingolipid analysis by liquid chromatography-electrospray ionization tandem mass spectrometry}

Sphingolipids were extracted and analyzed by liquid chromatography-electrospray ionization tandem mass spectrometry (LC-ESI-MS/MS) as described previously [14]. The amounts of individual sphingolipid species were added to obtain the total sphingolipid pool. Protein content of pooled OptiPrep gradient fractions was determined as described by Smith et al. [16].

Detection of Abcc1/ABCC1-mediated efflux by flow cytometric analysis

Neuro-2a or BHK-MRP1 cells were plated to confluence in $25 \mathrm{~cm}^{2}$ flasks one day prior to the experiment. Abcc1/ABCC1-mediated efflux of the substrate 5-carboxyfluorescein diacetate was performed by flow cytometric analysis as described [18].

\section{Measurement of cellular sensitivity to cytotoxic drugs (MTT assay)}

One thousand cells/well were plated in microtiter plates. For depletion of cholesterol, cells were washed $24 \mathrm{~h}$ after plating with serum-free medium and incubated in the presence of 10 $\mathrm{mM}$ M- $\beta-\mathrm{CD}$ in serum-free medium for $1 \mathrm{~h}$ at $37^{\circ} \mathrm{C}$. Subsequently, cells were washed with serum-free medium and incubated for $48 \mathrm{~h}$ in serum-containing medium. Viable cells were determined $72 \mathrm{~h}$ after plating as previously described [14].

\section{Isolation of membrane vesicles from BHK-MRP1 cells}

BHK-MRP1 cells were washed with HBSS, trypsinized, harvested and treated, then centrifuged (3000 rpm, $3 \mathrm{~min}$ ), frozen in liquid nitrogen and stored in $-80^{\circ} \mathrm{C}$. Pellets of $\sim$ $8 \times 10^{8}$ frozen cells were resuspended in hypotonic solution $(5 \mathrm{mM}$ sodium phosphate, $\mathrm{pH} 7.4$, containing protease inhibitors and $1 \mathrm{mM}$ EDTA) by stirring for $90 \mathrm{~min}$ on ice. After centrifugation $\left(100000 \times \mathrm{g}, 45 \mathrm{~min}, 4{ }^{\circ} \mathrm{C}\right)$ cell material was resuspended in isotonic buffer $(10$ $\mathrm{mM}$ Tris, $\mathrm{pH} 7.4,250 \mathrm{mM}$ sucrose, containing protease inhibitors and $1 \mathrm{mM}$ EDTA) and homogenized using a Dounce tissue grinder. The material was carefully layered on top of a $38 \%$ sucrose solution and centrifuged $\left(280000 \mathrm{x} \mathrm{g,} 2 \mathrm{~h}, 4^{\circ} \mathrm{C}\right)$. The membrane interface was collected and diluted in isotonic buffer and centrifuged again $\left(100000 \mathrm{x} \mathrm{g}, 45 \mathrm{~min}, 4^{\circ} \mathrm{C}\right)$. The membrane pellet was finally resuspended in isotonic buffer at a concentration of $5 \mathrm{mg} / \mathrm{ml}$ of protein [16], frozen in liquid nitrogen and stored at $-80^{\circ} \mathrm{C}$.

\section{Measurement of ABCC1-mediated ATPase and transport activities}

Vanadate sensitive ATPase activites were measured as described earlier [19,20]. Briefly, isolated membranes ( $8 \mu \mathrm{g} /$ well) were incubated for $11 \mathrm{~min}$ in $50 \mu 1$ ATPase assay mix (40 mM MOPS-Tris $\mathrm{pH} 7.0$, containing $10 \mathrm{mM} \mathrm{MgCl}_{2}, 50 \mathrm{mM} \mathrm{KCl}, 5 \mathrm{mM}$ dithiothreitol, $0.1 \mathrm{mM}$ EGTA, $4 \mathrm{mM} \mathrm{Na-azide,} \mathrm{and} 5 \mathrm{mM}$ ATP). The reaction was stopped with $100 \mu \mathrm{l}$ malachite green mix [21-25], as modified in our lab (5.6 mM malachite green, $9.4 \mathrm{mM}$ ammoniummolybdate, $2 \%$ citric acid, $4.6 \%$ ethanol, and $1.16 \mathrm{~N} \mathrm{HCl}$, final concentration). After two 
min $100 \mathrm{ul}$ of citric acid was added and incubated at $37{ }^{\circ} \mathrm{C}$ for $15-20 \mathrm{~min}$. The absorbance values were measured using a spectrophotometer (Biotek uQuant) at a wavelength of $630 \mathrm{~nm}$. For transport of cysteinyl leukotriene $\mathrm{C}_{4}\left(\mathrm{LTC}_{4}\right)$ into membrane vesicles, vesicles were incubated as described before [26] in $40 \mathrm{mM}$ MOPS-Tris $\mathrm{pH} 7.0,180 \mathrm{mM}$ sucrose, containing $10 \mathrm{mM} \mathrm{MgCl}_{2}, 20 \mathrm{mM} \mathrm{KCl}, 47.8 \mathrm{nM} \mathrm{LTC}_{4}$ and with or without $4 \mathrm{mM} \mathrm{ATP}$, for various time intervals at $37^{\circ} \mathrm{C}$. $\mathrm{LTC}_{4}$ at a concentration of $47 \mathrm{nM}$ was mixed with ${ }^{3} \mathrm{H}-\mathrm{LTC}_{4}$ (specific activity of $190 \mathrm{Ci} / \mathrm{mmol}$ ) at a concentration of $0.8 \mathrm{nM}$. The reaction was stopped with ice cold washing buffer (10 mM Tris $\mathrm{pH} 7.0,180 \mathrm{mM}$ sucrose, $20 \mathrm{mM} \mathrm{KCl})$. The reaction mix was rapidly filtered in glass fibre filter plates (Whatman GF/C short drop), washed with $5 \times 200 \mu 1$ ice cold washing buffer, and dried. Radioactivity was measured by liquid scintillation counting (Packard Topcount microplate scintillation counter). ATPase activity was expressed as $\mathrm{pmol} \mathrm{Pi} / \mathrm{mg} / \mathrm{min}$ and transport into membrane vesicles as $\mathrm{pmol} \mathrm{LTC}_{4} / \mathrm{mg} / \mathrm{min}$. For graphic representation, values were normalized to maximal activity in control conditions $(=100 \%)$.

\section{Measurement inside-out vesicle content}

Determination of the inside-out vesicle ratio was based on 5'-nucleotidase activity and performed as described earlier [27] with the following changes: 25-50 $\mu \mathrm{g}$ of membrane vesicles was incubated $\left(30 \mathrm{~min}, 37^{\circ} \mathrm{C}\right)$ in $50 \mathrm{mM}$ Tris, $\mathrm{pH} 7.4$, containing $4 \mathrm{mM} \mathrm{MgCl}_{2}$, and with or without $3 \mathrm{mM}$ AMP and/or $0.3 \%$ Triton X-100. The inorganic phosphate released by the 5'-nucleotidase was measured with the malachite green system as described above. 5'nucleotidase activity was measured in 4 conditions; A: with AMP and Triton X-100, B: with AMP, without Triton X-100, C: without AMP, with Triton X-100 and D: without AMP, without Triton X-100. A-C yields the total activity of the enzyme, B-D the activity of the right side-out vesicles only. The percentage of inside out vesicles was calculated as [(A-C)-(BD)] $100 /(A-C)$. 


\section{Results}

Efficient depletion or uploading of cholesterol

First we established the efficacy of cholesterol modulation, using three different strategies. 1) M- $\beta-C D$ was used to physically deplete cholesterol from cell membranes. 2) Lovastatin, an inhibitor of 3-hydroxy-3methylglutaryl-coenzyme A reductase, plus RO 48-8071, an inhibitor of oxidosqualene cyclase, were used to inhibit the biosynthesis of cholesterol. 3) Cholesterol oxidase was used to chemically convert cholesterol to cholestenon.

The results are summarized in Table 1 . In Neuro-2a cells a $1 \mathrm{~h}$ treatment with $10 \mathrm{mM}$ M- $\beta-C D$ decreased the cholesterol level by $71.6 \%$ in whole cells. In detergent free lipid raft fractions from these cells, cholesterol was even more strongly depleted $(87.0 \%)$. In BHKMRP1 cells cholesterol depletion by M- $\beta-C D$ was $64.1 \%$. The M- $\beta-C D$ treatment slightly affected Neuro-2a cell viability, as determined by a MTT assay. Neuro-2a cell viability was $81.4 \% \pm 18.6 \%(\mathrm{n}=6)$ for $\mathrm{M}-\beta$-CD-treated cells $(1 \mathrm{~h})$ compared to control cells $(=100 \%)$.

Conditions for inhibition of cholesterol biosynthesis in Neuro-2a cells were optimized in terms of concentrations and time of incubation (data not shown). Cells incubated for $20 \mathrm{~h} \mathrm{in}$ the presence of both $1 \mu \mathrm{g} / \mathrm{ml}$ lovastatin and $1 \mu \mathrm{M}$ RO $48-8071$ showed a $52.9 \%$ decrease of the cholesterol level. Finally, when $1 \mathrm{U} / \mathrm{ml}$ cholesterol oxidase was used for $1 \mathrm{~h}$ in Neuro-2a cells, the cholesterol content was reduced by $29.0 \%$. In BHK-MRP1 cells, the enzyme was much more efficient, reducing cholesterol by $96.3 \%$.

The cholesterol levels in cell membranes isolated from cholesterol-modulated BHKMRP1 cells are summarized in Table 2. Cholesterol oxidase treatment of intact BHK-MRP1 cells resulted in a maximal decrease in cholesterol level of $\sim 50 \%$ in the isolated cell membranes. This was less efficient compared to previous experiments (Table 1), possibly due to the use of large scale cell cultures needed for the subsequent isolation of membranes. We also treated isolated membrane vesicles with cholesterol oxidase, but this resulted in degradation of ABCC1 (Supplementary Figure S1 at http://www.BiochemJ.org/bj/) and these preparations were therefore not suitable for analysis of $\mathrm{ABCC} 1$ function. ABCC1 was not degraded in membrane preparations obtained from cholesterol-modulated BHK-MRP1 cells, as compared to control membrane preparations (Supplementary Figure S1 at http://www.BiochemJ.org/bj/).

Cholesterol depletion by M- $\beta-C D$ treatment reduced cholesterol by $\sim 57 \%$ in isolated membranes, while cholesterol uploading with $\mathrm{M}-\beta-\mathrm{CD} / \mathrm{cholesterol} \mathrm{increased} \mathrm{the} \mathrm{cholesterol}$ level by $\sim 58 \%$. The cholesterol content of control membrane vesicles was $240 \pm 30 \mathrm{nmol}$ cholesterol/mg protein $(n=9)$.

\section{Cholesterol does not affect efflux function of Abcc1/ABCC1}

Having established the extent of cholesterol modulation with three different strategies, we next measured the effects on Abcc1/ABCC1-mediated CFDA efflux. Efflux activity was the same in cholesterol oxidase-treated and control cells, regarding both Neuro-2a (Fig. 1A) and BHK-MRP1 (Fig. 1B) cells. Also in lovastatin/RO 48-8071-treated Neuro-2a cells, efflux activity was similar to control (Fig. 1C). MK571 was used as a positive control for inhibition of Abcc1/ABCC1-mediated efflux (Fig. 1A-C). With M- $\beta$-CD differential effects on Abcc1/ABCC1-mediated efflux kinetics were observed in the two cell types. In Neuro-2a cells, efflux activity was normal up to $10 \mathrm{~min}$ of $\mathrm{M}-\beta-\mathrm{CD}$ treatment, but was reduced after 30 min and maximally affected after 45 min treatment (Fig. 2A). In BHK-MRP1 cells, on the other hand, ABCC1-mediated efflux activity was already reduced after $10 \mathrm{~min}$ of $\mathrm{M}-\beta-\mathrm{CD}$ treatment, and subsequently kept fluctuating around this level (Fig. 2B). It was therefore important to measure in parallel the kinetics of cholesterol depletion in both cell types, which turned out to be very similar in Neuro-2a and BHK-MRP1 cells (Supplementary Figure S2 at http://www.BiochemJ.org/bj/). Cholesterol levels were equally decreased at $\mathrm{t}=10 \mathrm{~min}$ in both 
cell types (Supplementary Figure S2 at http://www.BiochemJ.org/bj/). Interestingly, upon longer M- $\beta$-CD treatment, both cell types became sensitive to MK571, as indicated by loss of Abcc1/ABCC1 substrate likely due to membrane leakage. This occurred between 45 and 60 min for Neuro-2a (Fig. 2C) and between 15 and 30 min for BHK-MRP1 cells (Fig. 2D).

Abcc1/ABCC1 efflux function is not correlated with its localization in lipid rafts We used a detergent-free method for the isolation of lipid rafts and first characterized the gradient fractions in terms of cholesterol and sphingolipid enrichment. For this purpose, fractions 1-2 were pooled, as well as 3-4, 5-6 and 7-9. Fractions 1-2 were most strongly enriched in both cholesterol and sphingolipids (Supplementary Figure S3 at $\mathrm{http}: / / \mathrm{www}$. BiochemJ.org/bj/), and to a lesser extent also fractions 3-4. This indicates that fractions 1-2, with the lowest buoyant density, optimally fulfil the criteria for lipid rafts. In accordance with the absence of an effect of cholesterol oxidation on Abcc1 efflux function, there was no effect on detergent-free lipid raft localization of the $\mathrm{ABC}$ transporter, as indicated by a similar gradient profile of Abcc 1 compared to control Neuro-2a cells (Fig. 3A). Cholesterol oxidase was much more effective in reducing cholesterol content in BHK-MRP1 cells than in Neuro-2a cells. Therefore, we also rigorously tested lipid raft association of ABCC1 under cholesterol oxidase conditions in BHK-MRP1 cells and this turned out to be equal to control cells, as confirmed by quantification of the lipid raft-associated pools (Fig. 3B).

On the other hand, lovastatin/RO 48-8071 treatment did result in a clear shift of Abcc1 out of detergent-free lipid raft fractions in Neuro-2a cells, as confirmed by quantification of the relative amount of Abcc 1 in lipid raft fractions (Fig. 3C). Upon M- $\beta$-CD treatment, detergent-free lipid raft association of Abcc1 was gradually reduced in Neuro-2a cells and this was significant after 60 min (Fig. 4A). In BHK-MRP1 cells, ABCC1 showed a tendency to shift out of lipid raft gradient fractions only after $60 \mathrm{~min} M-\beta-C D$ treatment, but this did not reach significance due to large variation (Fig. 4B).

\section{ABCC1 ATPase and transport activities are not correlated with cholesterol levels in isolated cell membranes}

The absence of effects of cholesterol modulation on Abcc1/ABCC1 function could have been due to confounding factors in the complex background of the intact cell. To overcome the complexity of the cell system, plasma membrane vesicles were isolated from cholesterol modulated BHK-MRP1 cells. To make sure that our procedures to modulate cholesterol in cells did not affect the inside-out ratio of $\mathrm{ABCC} 1$ in the isolated membrane vesicles, we measured this ratio. Under all conditions, the inside-out vesicle ratio was found to be invariable (Supplementary Figure S4 at http://www.BiochemJ.org/bj/). Moreover, ABCC1 integrity was not changed by our cholesterol modulation procedures, as shown by Western blot (Supplementary Figure S1 at http://www.BiochemJ.org/bj/).

In this simplified system for $\mathrm{ABCC} 1$ function analysis, we measured ATPase activity of ABCC1 as well as transport of $\mathrm{LTC}_{4}$ into membrane vesicles by $\mathrm{ABCC} 1$ (Fig. 5). The average vanadate sensitive ATPase activity and transport of $\mathrm{LTC}_{4}$ into isolated control plasma membranes were $34 \pm 9 \mathrm{pmol} \mathrm{Pi} / \mathrm{mg} / \mathrm{min}(\mathrm{n}=27)$ and $74 \pm 39 \mathrm{pmol} / \mathrm{mg} / \mathrm{min}(\mathrm{n}=27)$,

respectively, There were no significant differences between cholesterol depleted (cholesterol oxidase or $M-\beta-C D$ treated) or cholesterol uploaded (M- $\beta-C D /$ cholesterol treated) membranes on the one hand and control membranes on the other (Fig. 5 and Supplementary Table S1 at http://www.BiochemJ.org/bj/). The average $\mathrm{V}_{\max }$ and $\mathrm{K}_{\mathrm{m}}$ values of the transport of $\mathrm{LTC}_{4}$ into membrane vesicles were $661 \pm 171 \mathrm{pmol} / \mathrm{mg} / \mathrm{min}$ and $942 \pm 220 \mathrm{nM}$, respectively. These kinetic parameters of the $\mathrm{LTC}_{4}$ transport did not show any statistical differences between cholesterol-modulated and control membranes (data not shown). 


\section{Discussion}

With regard to cholesterol-modulated $\mathrm{ABC}$ transporter activity, most studies have focused on P-glycoprotein. These studies have generated much information, but unfortunately not a coherent picture of whether and how cholesterol affects P-glycoprotein function [6,28]. Concerning modulation of $\mathrm{Abcc} 1 / \mathrm{ABCC} 1$ by cholesterol, very little information is available. One study shows that when the cellular cholesterol level is lowered, ABCC1 function is reduced and concomitantly ABCC1 shifts out of lipid rafts in GLC4 multidrug-resistant lung cancer cells [9]. This conclusion was based on results obtained solely with M- $\beta$-CD treatment. In our study, we obtained similar effects of $M-\beta-C D$ treatment. However, we did not attribute these effects to cholesterol, in view of the results obtained with the additional procedures for cholesterol modulation, i.e. cholesterol oxidase and lovastatin plus RO 48-8071. Abcc1/ABCC1-mediated efflux was not affected in these two treatment protocols, while the cholesterol level was strongly decreased, especially in cholesterol oxidase-treated BHKMRP1 cells. Moreover, with M- $\beta$-CD treatment efflux was dissociated from the cholesterol level, since short-term treatment did affect efflux in BHK-MRP1, but not in Neuro-2a cells, while cholesterol levels were equally decreased in the two cell types. Long-term M- $\beta-C D$ treatment in Neuro-2a cells decreased both cholesterol levels and Abccl-mediated efflux. However, long-term M- $\beta$-CD treatment has been shown to result in side effects, such as removal of other lipids and potentially even proteins from membranes [8,29]. Thus, interpretation of such studies should be done with care. The data obtained with MK571 as inhibitor of Abcc1/ABCC1 efflux show that after short-term M- $\beta$-CD treatment the residual cell associated substrate is high, as expected. However, after long-term M- $\beta$-CD treatment substrate is lost from MK571-treated cells, suggesting that MK571 becomes toxic in combination with $\mathrm{M}-\beta-\mathrm{CD}$. This would indicate that membranes gradually destabilize with $\mathrm{M}-\beta-\mathrm{CD}$ treatment. It is noteworthy that the $\mathrm{M}-\beta-\mathrm{CD}$ effect becomes apparent at shorter incubation times in BHK-MRP1 cells, as compared to Neuro-2a cells. This could be related to the fact that BHK-MRP1 cells were subjected to forced expression of human ABCC1, possibly resulting in less stable integration of $\mathrm{ABCC} 1$ in the plasma membrane. As a consequence, $\mathrm{ABCC} 1$ would become more prone to the destabilizing effects of $\mathrm{M}-\beta-\mathrm{CD}$. On the other hand, when the M- $\beta-C D$ effect on Neuro-2a cells sets in, it is more pronounced compared to that in BHK-MRP1 cells.

The studies on intact cells were extended to isolated membrane vesicles to overcome potential confounding effects in the complex system of the intact cell. The modulation of cholesterol performed on the cells did not change the integrity and inside-out ratio of ABCC1 in the vesicles consisting of isolated membranes from these cells, allowing us to properly measure potential effects on $\mathrm{ABCC} 1$ function. Data on $\mathrm{ABCC} 1$ function in these vesicles with decreased cholesterol levels confirm the conclusion that $\mathrm{ABCC} 1$ function does not depend on cholesterol. In addition, uploading of cholesterol was ineffective with regard to the function of $\mathrm{ABCC} 1$. Moreover, this shows that our results are not specific for the Abcc1/ABCC1 substrate CFDA, since in this assay for $\mathrm{ABCC} 1$ function in vesicles from isolated membranes a completely different substrate $\left(\mathrm{LTC}_{4}\right)$ was used.

Next we explored whether Abcc1/ABCC1-mediated efflux activity was related to localization of $\mathrm{Abcc1} / \mathrm{ABCC} 1$ in cholesterol-stabilized lipid rafts. Comparison of results revealed that all 4 combinations of "effect/no effect" on these two parameters occurred. 1) After cholesterol oxidase treatment, both Abcc1/ABCC1-mediated efflux and its localization in lipid rafts were unaffected. 2) Upon long-term $M-\beta-C D$ treatment both efflux and lipid raft localization of Abcc1/ABCC1 were reduced. 3) On the other hand, with short-term M- $\beta-C D$ treatment in BHK-MRP1 cells, efflux was affected, while raft localization was normal. 4) The opposite occurred after lovastatin plus RO 48-8071-treatment, which resulted in a shift of Abccl out of lipid raft fractions without any effect on efflux activity. Given the fact that all 
possible combinations of "effect/no effect" on these 2 parameters occurred, we can conclude that Abcc1/ABCC1-mediated efflux activity and its localization in cholesterol-stabilized lipid rafts were not correlated. In a recent study we showed that Abcc1/ABCC1 efflux function was correlated with its localization in cortical actin-stabilized lipid rafts [18]. Therefore, we should not only consider that Abcc1/ABCC1 (and other ABC transporters as well) may behave differently between various cell types in terms of (lipid raft) localization-function coupling. In addition, it may well be that within a certain cell type, different types of lipid rafts exist, which are sensitive to either cholesterol or cortical actin, while only the latter is relevant for $\mathrm{ABCC} 1$ function.

Taken together, we thoroughly investigated potential effects of cholesterol on $\mathrm{Abcc1/ABCC1}$ function in two different cell lines and in vesicles from isolated membranes. Moreover, in order not to rely completely on M- $\beta-C D$ treatment we used 3 different cholesterol modulation procedures. Based in this comprehensive approach, we show for the first time that Abcc1/ABCC1 function can not be categorically linked to cholesterol levels or cholesterol-stabilized lipid raft localization in two different cell lines. A previous study did show an effect on ABCC1 function and localization by lowering the level of cholesterol in yet another cell line [9]. Therefore, studies in additional Abcc1/ABCC1 (over)expressing cell types have to be performed before more general conclusion can be drawn. In any case, cholesterol is not essential for $\mathrm{ABCC} 1$ function and therefore does not seem to take part in the mechanism underlying functional association of $\mathrm{ABCC} 1$ with lipid rafts, as has been observed for cortical actin [18]. 


\section{References}

1. Dudeja, P.K., Anderson, K.M., Harris, J.S., Buckingham, L. and Coon, J.S. (1995)

Reversal of multidrug resistance phenotype by surfactants: relationship to membrane lipid fluidity. Arch. Biochem. Biophys. 31, 309-315

2. Sinicrope, F.A., Dudeja, P.K., Bissonette, B.M. Safa, A.R. and Brasitus, T.A. (1992)

Modulation of P-glycoprotein-mediated drug transport by alterations in lipid fluidity of rat liver canalicular membrane vesicles. J. Biol. Chem. 267, 24995-25002

3. Lavie, Y., Fiucci, G. and Liscovitch, M. (1998) Up-regulation of caveolae and caveolar constituents in multidrug-resistant cancer cells. J. Biol. Chem. 273, 32380-32383

4. Hinrichs, J.W.J., Klappe, K., Hummel, I. and Kok, J.W. (2004) ATP-binding cassette transporters are enriched in non-caveolar detergent-insoluble glycosphingolipid-enriched membrane domains (DIGs) in human multidrug-resistant cancer cells. J. Biol. Chem. 279, 5734-5738

5. Radeva, G., Perabo, J. and Sharom, F.J. (2005) P-Glycoprotein is localized in intermediatedensity membrane microdomains distinct from classical lipid rafts and caveolar domains. FEBS J. 272, 4924-4937

6. Orlowksi, S., Martin, S. and Escargueil, A. (2006) P-glycoprotein and 'lipid rafts': some ambiguous mutual relationships (floating on them, building them or meeting them by chance?). Cell. Mol. Life Sci. 63, 1038-1059

7. Troost, J., Lindenmaier, H., Haefeli, W.E. and Weiss, J. (2004) Modulation of cellular cholesterol alters P-glycoprotein activity in multidrug-resistant cells. Mol. Pharmacol. 66, 1332-1339

8. Yunomae, K., Arima, H., Hirayama, F. and Uekama, K. (2003) Involvement of cholesterol in the inhibitory effect of dimethyl- $\beta$-cyclodextrin on P-glycoprotein and MRP2 function in Caco-2 cells. FEBS Lett. 536, 225-231

9. Marbeuf-Gueye, C., Stierle, V., Sudwan, P., Salerno, M. and Garnier-Suillerot, A. (2007)

Perturbation of membrane microdomains in GLC4 multidrug-resistant lung cancer cells-modification of ABCC1 (MRP1) localization and functionality. FEBS J. 274, 1470-1480

10. Chang, X.-B., Hou, Y.-X. and Riordan, J.R. (1997) ATPase activity of purified multidrug resistance-associated protein. J. Biol. Chem. 272, 30962-30968

11. Munro, S. (2003) Lipid rafts: Elusive or illusive. Cell 115, 377-388

12. Heerklotz, H. (2002) Triton promotes domain formation in lipid raft mixtures. Biophys. J. 83, 2693-2701

13. Macdonald, J.L. and Pike, L.J. (2005) A simplified method for the preparation of detergent-free lipid rafts. J. Lipid. Res. 46, 1061-1067

14. Klappe, K., Dijkhuis, A.J., Hummel, I., Dam, A., Ivanova, P.T., Milne, S.B., Myers, D.S., Brown, H.A., Permentier, H., and Kok, J.W. (2010) Extensive sphingolipid depletion does not affect lipid raft integrity or lipid raft localization and efflux function of the ABC transporter MRP1. Biochem. J. 430, 519-529.

15. Bligh, E.J. and Dyer, W.J. (1959) A rapid method of total lipid extraction and purification. Can. J. Biochem. Physiol. 37, 911-917

16. Smith, P.K., Krohn, R.I., Hermanson, G.T., Mallia, A.K., Gartner, F.H., Provenzano, M.D., Fujimoto, E.K., Goeke, N.M., Olson, B.J. and Klenk, D.C. (1985) Measurement of protein using bicinchoninic acid. Anal. Chem. 150, 76-85

17. Gamble, W., Vaughan, M., Kruth, H.S. and Avignan, J. (1978) Procedure for determination of free and total cholesterol in micro- or nanogram amounts suitable for studies with cultured cells. J. Lipid Res. 19, 1068-1070

18. Hummel, I., Klappe, K., Ercan, C. and Kok, J.W. (2010) MRP1 function and localization depend on cortical actin. Mol. Pharm. 79, 229-240 
19. Sarkadi, B., Price, E.M., Boucherg, R.C., Germannil, U.A. and Scarborough, G.A. (1992) Expression of the Human Multidrug Resistancec DNA in Insect Cells Generates a High Activity Drug-stimulated Membrane ATPase. J. Biol. Chem. 267, 4854-4858

20. Glavinas, H., Kis, E., Pál, A., Kovács, R., Jani, M., Vági, E., Molnár, E., Bánsághi, S., Kele, Z., Janáky, T., Báthori, G., von Richter, O., Koomen, G.J. and Krajcsi, P. (2007) ABCG2 (breast cancer resistance protein/mitoxantrone resistance-associated protein) ATPase assay: a useful tool to detect drug-transporter interactions. Drug Metab. Dispos. 35,1533-1542 21. Hess H.H. and Derr, J.E. (1975) Assay of Inorganic and Organic Phosphorus in the 0.1-5 Nanomole Range. Anal. Biochem. 63, 607-613

22. Veldhoven, P.P. van, and Mannaerts, G. (1987) Inorganic and Organic Phosphate Measurements in the Nanomolar Range. Anal. Biochem. 161, 45-48 23. D’Angelo, E., Crutchfield, J. and Vandiviere, M. (2001) Rapid, Sensitive, Microscale Determination of Phosphate in Water and Soil J. Environ. Qual. 30, 2206-2209

24. Carter, S.G. and Karl, D.W. (1982) Inorganic phosphate assay with malachite green: An improvement and evaluation. J. Biochem. Biophys. Meth. 7, 7-13

25. Rumsfeld, J., Ziegelbauer, K. and Spaltmann, F. (2000) High-Throughput Assay for Inorganic Pyrophosphatases Using the Cytosolic Enzymes of Saccharomyces cerevisiae and Human as an Example. Protein Expression and Purification 18, 303-309

26. Pál A., Méhn, D., Molnár, E., Gedey, S., Mészáros, P., Nagy, T., Glavinas, H., Janáky, T., von Richter, O., Báthori, G., Szente, L. and Krajcsi, P. (2007) Cholesterol potentiates ABCG2 activity in a heterologous expression system: improved in vitro model to study function of human ABCG2. J. Pharmacol. Exp. Ther. 321, 1085-1094

27. Grinstein, S. and Cohen, S. (1983) Measurement of Sidedness of Isolated PlasmaMembrane Vesicles: Quantitation of Actin Exposure by DNase I Inactivation. Anal. Biochem. 130, 15 1-157

28. Kok, J.W., Klappe, K., Hummel, I., Kroesen, B.J., Sietsma, H. and Meszaros, P. (2008) Are lipid rafts involved in ABC transporter-mediated drug resistance of tumor cells? Trends Glycosci. Glycotechnol. 20, 373-397

29. Arima, H., Yunomae, K., Morikawa, T., Hirayama, F. and Uekama, K. (2004) Contribution of cholesterol and phospholipids to inhibitory effect of dimethyl-betacyclodextrin on efflux function of P-glycoprotein and multidrug resistance-associated protein 2 in vinblastine-resistant Caco-2 cell monolayers. Pharmaceutical Res. 21, 625-634 


\section{Figure legends}

Figure 1. Cholesterol modulation does not affect Abcc1/ABCC1-mediated efflux in Neuro-2a and BHK-MRPI cells

A,B: Neuro-2a (A) or BHK-MRP1 cells (B) were untreated (control) or treated with $1 \mathrm{U} / \mathrm{ml}$ cholesterol oxidase for $1 \mathrm{~h}(\mathrm{CO})$. C: Neuro-2a cells were untreated (control: $20 \mathrm{~h}$ in serumfree medium) or treated with $1 \mu \mathrm{g} / \mathrm{ml}$ lovastatin $+1 \mu \mathrm{M}$ RO $48-8071$ for $20 \mathrm{~h}$ in serum-free medium (LO/RO). Subsequently, cells were loaded with CFDA $(0.5 \mu \mathrm{M})$ and allowed to efflux at $37^{\circ} \mathrm{C}$ during several time intervals. The remaining cell-associated fluorescence was determined by cytometric analysis and expressed as \% of the 0 min value. Control: open squares; CO or LO/RO: closed squares. MK571 $(20 \mu \mathrm{M})$ was used as a positive control for Abcc1/ABCC1 efflux inhibition. Control + MK571: open triangles; CO + MK571 or LO/RO + MK571: closed triangles. Data represent the mean \pm SD $(n=3)$. 
Figure 2. Effects of $M-\beta-C D$ treatment on Abcc1/ABCC1-mediated efflux in Neuro-2a and BHK-MRPI cells

Neuro-2a (A,C) or BHK-MRP1 cells (B,D) were treated with $10 \mathrm{mM}$ M- $\beta$-CD for various time intervals. Subsequently, cells were loaded with CFDA $(0.5 \mu \mathrm{M})$ and allowed to efflux at $37^{\circ} \mathrm{C}$ for $5 \mathrm{~min}$. The remaining cell-associated fluorescence was determined by cytometric analysis and expressed as \% of the 0 min value. MK571 $(20 \mu \mathrm{M})$ was used as a control for Abcc1/ABCC1 efflux inhibition (C,D). Data represent the mean + SD ( $n=3)$. 
Figure 3. Detergent-free lipid raft localization of Abccl is affected by lovastatin/RO 48-8071 but not by cholesterol oxidase in Neuro-2a cells (and BHK-MRP1 cells)

Cells were untreated $(\mathrm{CON})$ or treated with either $1 \mathrm{U} / \mathrm{ml}$ cholesterol oxidase for $1 \mathrm{~h}(\mathrm{CO})$ or with $1 \mu \mathrm{g} / \mathrm{ml}$ lovastatin $+1 \mu \mathrm{M}$ RO $48-8071$ for $20 \mathrm{~h}$ in serum-free medium (LO/RO). A: Lipid raft association of Abcc1 in CO-treated Neuro-2a cells compared to control. B: Lipid raft association of $\mathrm{ABCC} 1$ in CO-treated BHK-MRP1 cells compared to control. C: Lipid raft association of $\mathrm{Abcc1}$ in $\mathrm{LO} / \mathrm{RO}$-treated Neuro-2a cells compared to control. The numbers indicate the percentage of $\mathrm{Abcc} 1 / \mathrm{ABCC} 1$ found in the pooled gradient fractions, relative to total Abcc1/ABCC1 in the entire gradient ( 9 fractions). Data represent the mean $+\mathrm{SD}(\mathrm{n}=3)$. Asterisks indicate values that are significantly different from $\operatorname{CON}(\mathrm{P}<0.05$, as determined by Student's $t$-test). The right panels show representative blots from three experiments concerning Abcc1/ABCC1 distribution along the gradient. Gradient samples were applied on SDS-PAGE based on equal volume. Lipid raft fractions are indicated. 
Figure 4. Effects of $M-\beta-C D$ treatment on detergent-free lipid raft localization of Abcc1/ABCC1 in Neuro-2a and BHK-MRP1 cells

Neuro-2a (A) or BHK-MRP1 cells (B) were untreated (0 min) or treated with $10 \mathrm{mM}$ M- $\beta$ $\mathrm{CD}$ for various time intervals $(5,30,60 \mathrm{~min})$ and lipid raft association of Abcc1/ABCC1 was determined under these conditions. The numbers indicate the percentage of Abcc1/ABCC1 found in the gradient fractions, relative to total Abcc1/ABCC1 in the entire gradient ( 9 fractions). Data represent the mean $+\mathrm{SD}(\mathrm{n}=3)$. Asterisks indicate values that are significantly different from CON ( $\mathrm{P}<0.05$, as determined by Student's $t$-test). The right panels show representative blots from three experiments concerning Abcc1/ABCC1 distribution along the gradient. Gradient samples were applied on SDS-PAGE based on equal volume. Lipid raft fractions are indicated. 
Figure 5. Vanadate sensitive ATPase activity and transport of $L_{T C} C_{4}$ into membrane vesicles by ABCC1 in cholesterol modified membrane vesicles

BHK-MRP1 cells were treated with cholesterol oxidase (CO; $1 \mathrm{U} / \mathrm{ml} ; \mathrm{A}, \mathrm{B}), \mathrm{M}-\beta-\mathrm{CD}(\mathrm{CD} ; 10$ $\mathrm{mM}$; C,D), or M- $\beta-\mathrm{CD} /$ cholesterol (CDC; $10 \mathrm{mM}$; E,F). Cell membranes were isolated from these cells and control cells. The vanadate sensitive ATPase activity $(\mathrm{A}, \mathrm{C}, \mathrm{E})$ or the transport of $\mathrm{LTC}_{4}$ into membrane vesicles $(\mathrm{B}, \mathrm{D}, \mathrm{F})$ by $\mathrm{ABCC} 1$ were measured. For each treatment, three independent membrane preparations were generated. For each membrane preparation, the measurements were performed in triplicate. Each data point in a curve represents the average \pm SD of three independent membrane preparations. (a) represents membranes from control cells and (b), (c) and (d) membranes from cells treated for various time intervals with $\mathrm{CO}, \mathrm{CD}$ or CDC, respectively. In case of CO, (b), (c) and (d) refer to 30,60 and $90 \mathrm{~min}$ treatment, respectively. In case of CD and CDC, this is 10, 20 and $30 \mathrm{~min}$. (a) solid line; (b) - dotted line; (c) $\mathbf{\Delta}$ dashed line; (d) $\bullet$ dashed dotted line. ATPase activity was expressed as $\mathrm{pmol} \mathrm{Pi} / \mathrm{mg} / \mathrm{min}$ and $\mathrm{LTC}_{4}$ transport as pmol LTC $4 / \mathrm{mg} / \mathrm{min}$. For graphic representation, values were normalized to maximal activity in control conditions $(=100 \%)$. 
TABLES

\begin{tabular}{|c|c|c|c|}
\hline Cell type & Fraction & Method & $\begin{array}{c}\text { Cholesterol content } \\
(\text { control }=100 \%)\end{array}$ \\
\hline Neuro-2a & whole cells & M- $\beta-C D$ & $28.4 \% \pm 12.3$ \\
\hline Neuro-2a & detergent-free lipid rafts & M- $\beta-C D$ & $13.0 \% \pm 7.5$ \\
\hline Neuro-2a & whole cells & lovastatin + RO $48-8071$ & $47.1 \% \pm 7.8$ \\
\hline Neuro-2a & whole cells & cholesterol oxidase & $71.0 \% \pm 5.0$ \\
\hline BHK-MRP1 & whole cells & M- $\beta-C D$ & $35.9 \% \pm 3.0$ \\
\hline BHK-MRP1 & whole cells & cholesterol oxidase & $3.7 \% \pm 2.1$ \\
\hline
\end{tabular}

Table 1: Cholesterol depeletion methods and efficiency in intact cells

Various procedures were performed to manipulate cholesterol levels, including M- $\beta$-CD treatment $(10 \mathrm{mM}, 1 \mathrm{~h})$, which physically removes cholesterol from the plasma membranes of cells, cholesterol oxidase treatment $(1 \mathrm{U} / \mathrm{ml}, 1 \mathrm{~h})$, which chemically converts cholesterol into cholestenon and combined treatment with lovastatin $(1 \mu \mathrm{g} / \mathrm{ml})$, an inhibitor of 3-hydroxy3methylglutaryl-coenzyme A reductase and RO 48-8071 $(1 \mu \mathrm{M})$, an inhibitor of oxidosqualene cyclase. Cholesterol content was measured and normalized to protein. These values were normalized to control $(=100 \%)$. Data indicate the mean \pm SD of three independent measurements. 


\begin{tabular}{|c|c|c|c|c|c|}
\hline \multicolumn{2}{|c|}{$\begin{array}{c}\text { Cholesterol depletion with } \\
\text { Cholesterol Oxidase (CO) }\end{array}$} & \multicolumn{2}{c|}{$\begin{array}{c}\text { Cholesterol depletion with } \\
\text { M- } \beta \text {-Cyclodextrin (CD) }\end{array}$} & \multicolumn{2}{c|}{$\begin{array}{c}\text { Cholesterol upload with } \\
\text { M- } \beta \text {-CD/cholesterol (CDC) }\end{array}$} \\
\hline Treatment & Cholesterol (\%) & Treatment & Cholesterol (\%) & Treatment & Cholesterol (\%) \\
\hline $\mathrm{COa}$ & 100 & $\mathrm{CDa}$ & 100 & $\mathrm{CDCa}$ & 100 \\
\hline $\mathrm{COb}$ & $75 \pm 1,8$ & $\mathrm{CDb}$ & $71 \pm 4,8$ & $\mathrm{CDCb}$ & $136 \pm 15,2$ \\
\hline $\mathrm{COc}$ & $63 \pm 6,8$ & $\mathrm{CDc}$ & $53 \pm 2,6$ & $\mathrm{CDCc}$ & $143 \pm 17,7$ \\
\hline $\mathrm{COd}$ & $52 \pm 1,2$ & $\mathrm{CDd}$ & $43 \pm 5.1$ & $\mathrm{CDCd}$ & $158 \pm 23,3$ \\
\hline
\end{tabular}

Table 2: Cholesterol modulation methods and efficiency in isolated membranes from BHK-MRP1 cells

BHK-MRP1 cells were treated during various time intervals with cholesterol oxidase (CO; 1 $\mathrm{U} / \mathrm{ml}), \mathrm{M}-\beta-\mathrm{CD}(\mathrm{CD} ; 10 \mathrm{mM})$, or $\mathrm{M}-\beta-\mathrm{CD} /$ cholesterol $(\mathrm{CDC} ; 10 \mathrm{mM})$. Each treatment was performed independently three times, resulting in three independent membrane preparations. Cholesterol content was measured and normalized to protein. These values were normalized to control $(=100 \%)$. Data indicate the mean $\pm \mathrm{SD}$ of three independent membrane preparations. (a) represents membranes from control cells and (b), (c) and (d) membranes from cells treated for various time intervals with $\mathrm{CO}, \mathrm{CD}$ or CDC, respectively. In case of $\mathrm{CO},(\mathrm{b}),(\mathrm{c})$ and (d) refer to 30, 60 and 90 min treatment, respectively. In case of CD and $\mathrm{CDC}$, this is 10,20 and $30 \mathrm{~min}$. 
A Neuro-2a

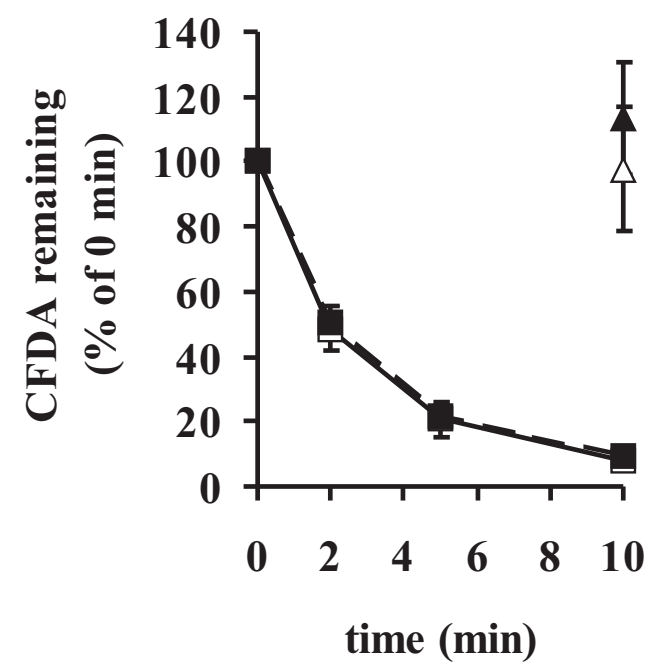

\section{B BHK-MRP1}

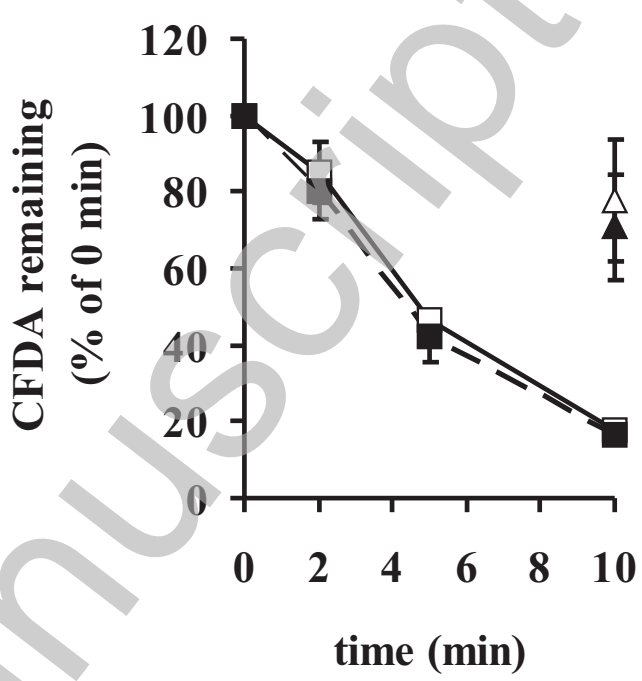

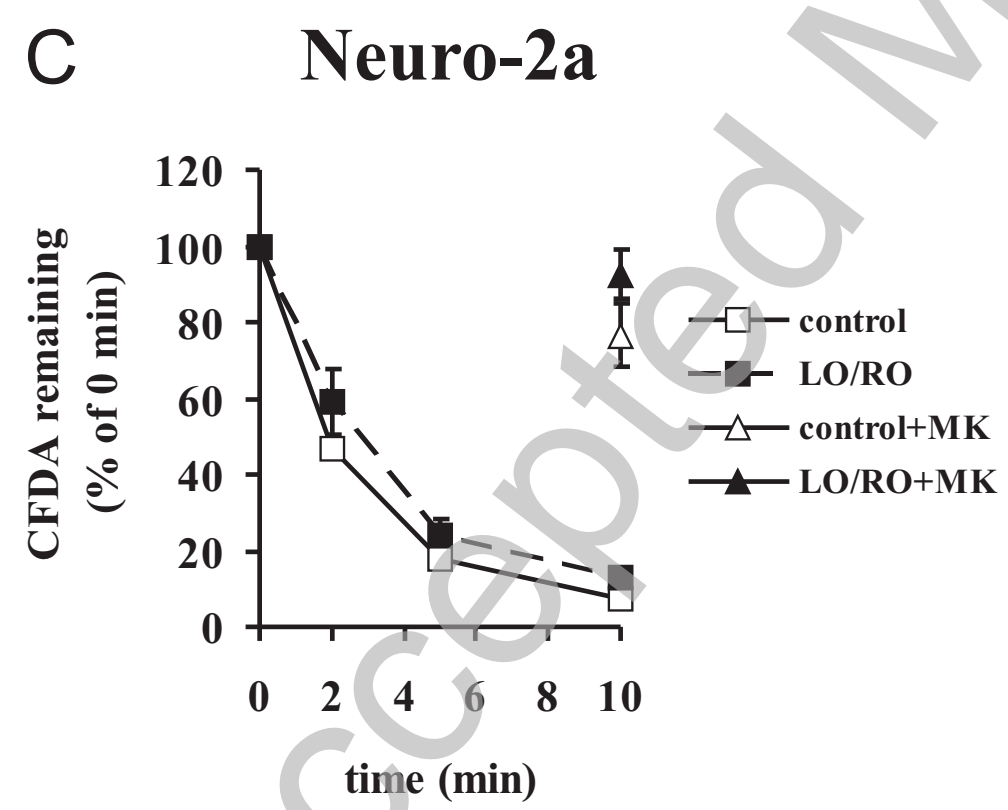

Figure 1

Licenced copy. Copying is not permitted, except with prior permission and as allowed by law. 


\section{$\begin{array}{llll}\text { A } & \text { Neuro-2a } & B & \text { BHK-MRP1 }\end{array}$}
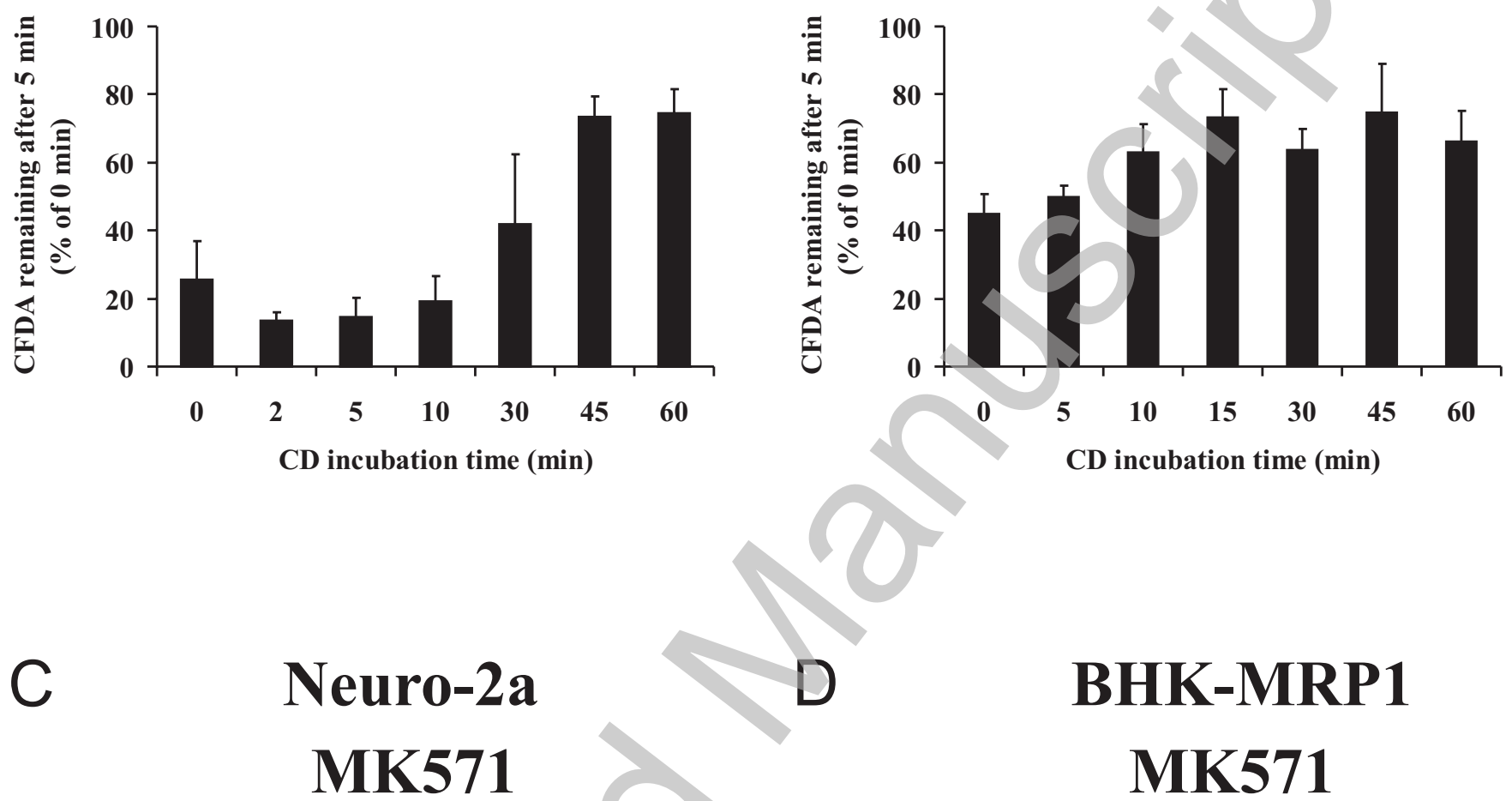

BHK-MRP1

MK571
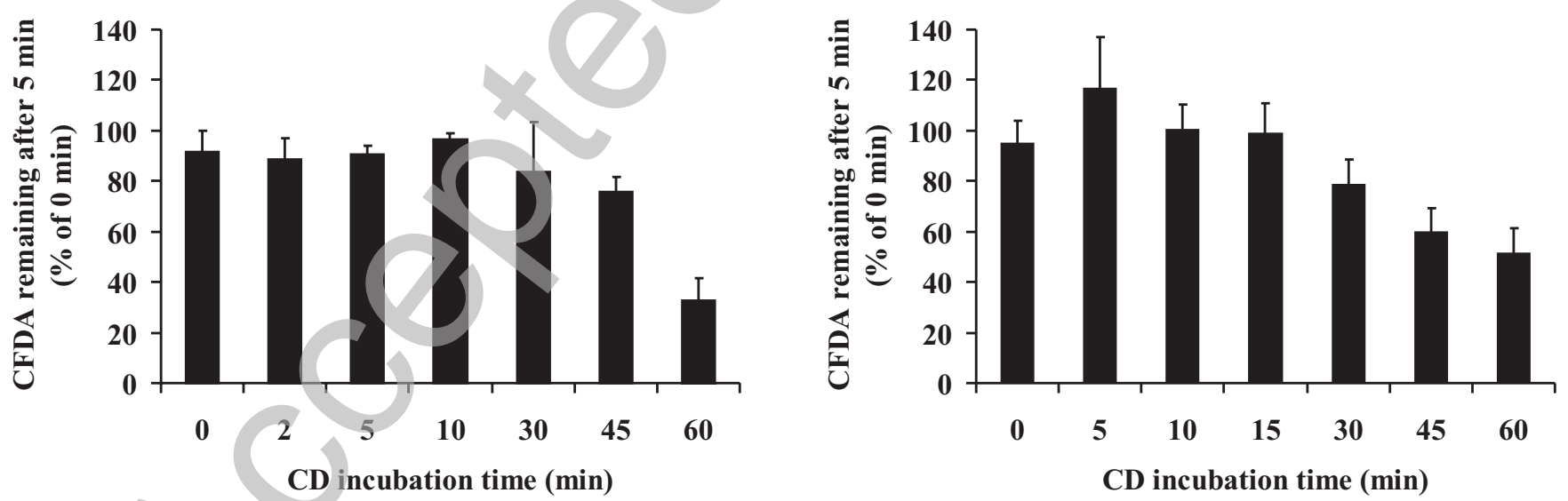

Figure 2

Licenced copy. Copying is not permitted, except with prior permission and as allowed by law.

(C) 2011 The Authors Journal compilation (C) 2011 Portland Press Limited 
A

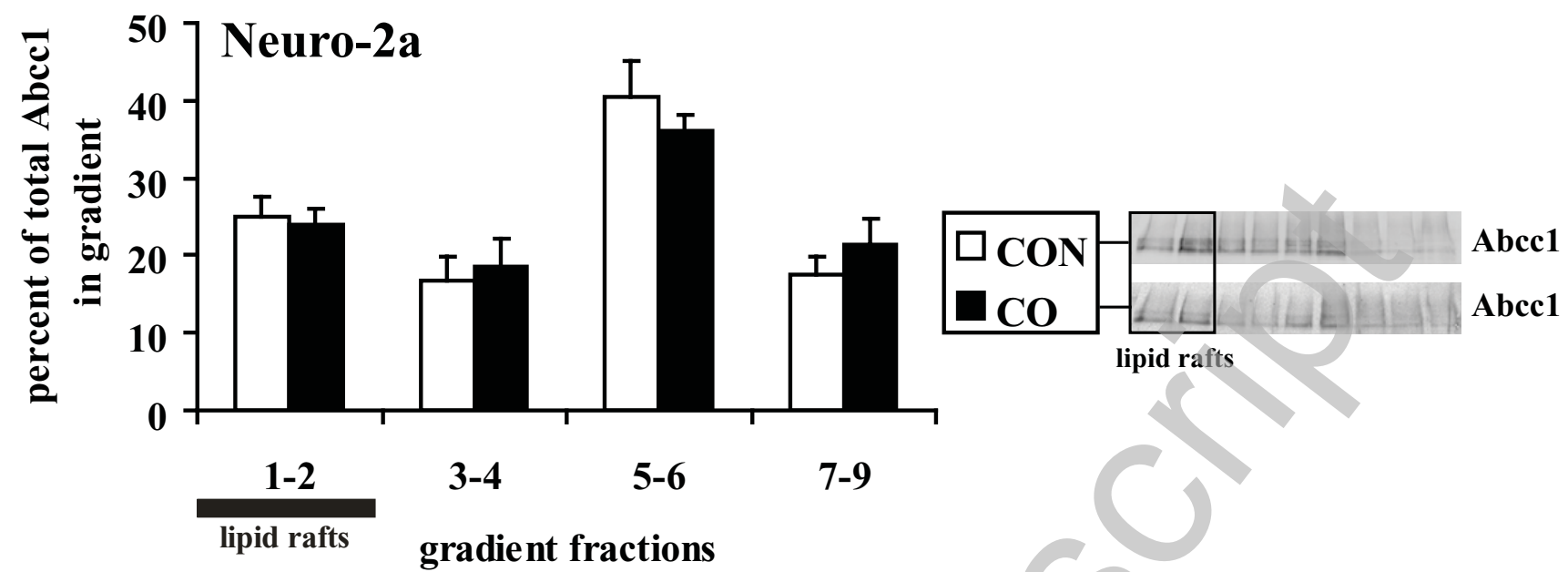

B

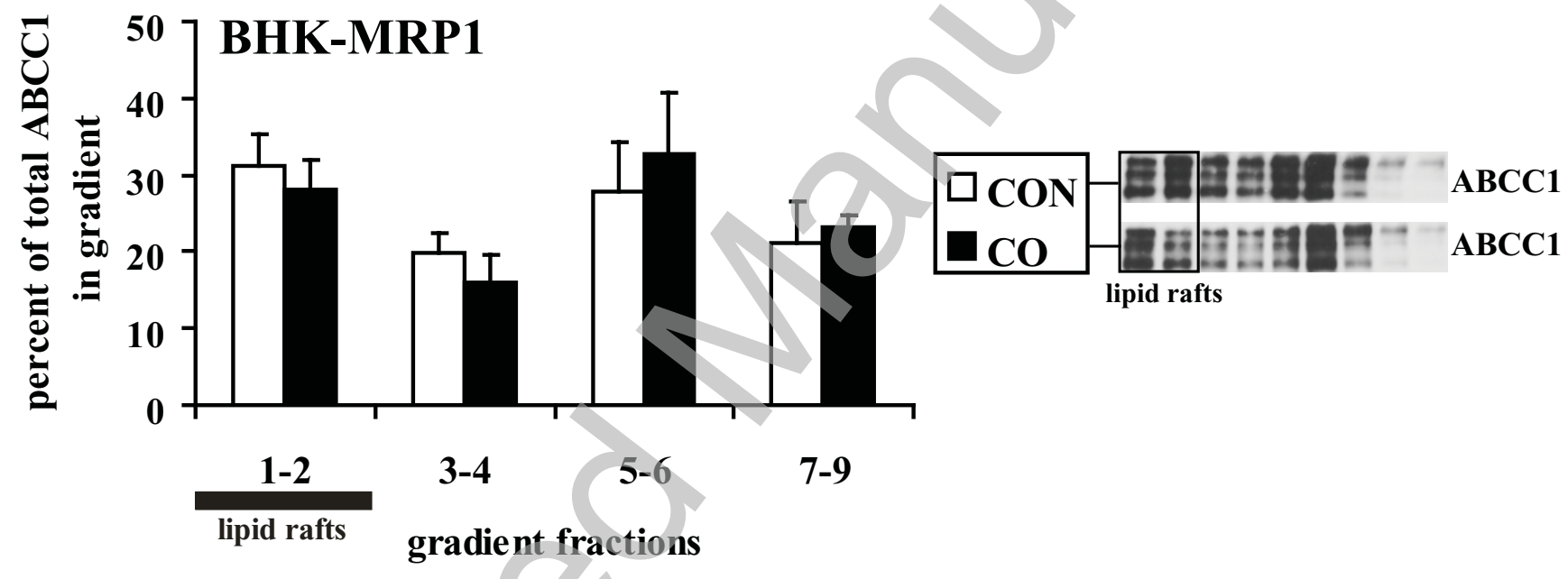

C

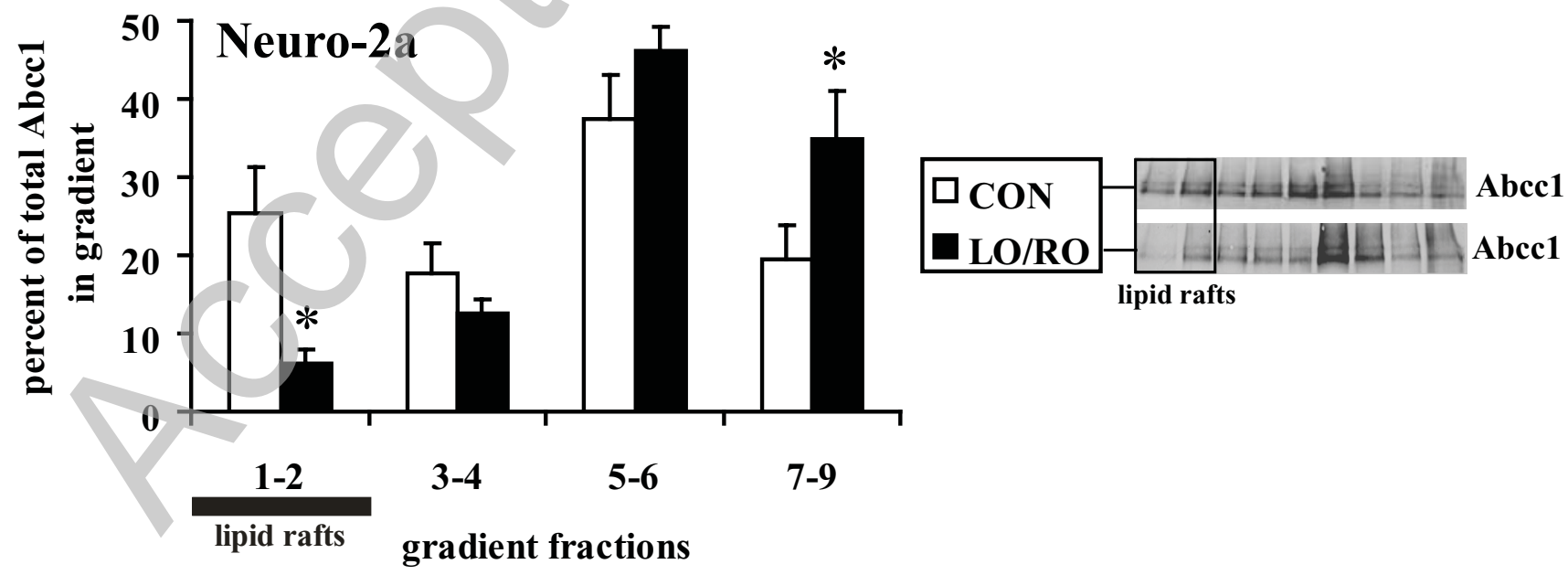

Figure 3 
A
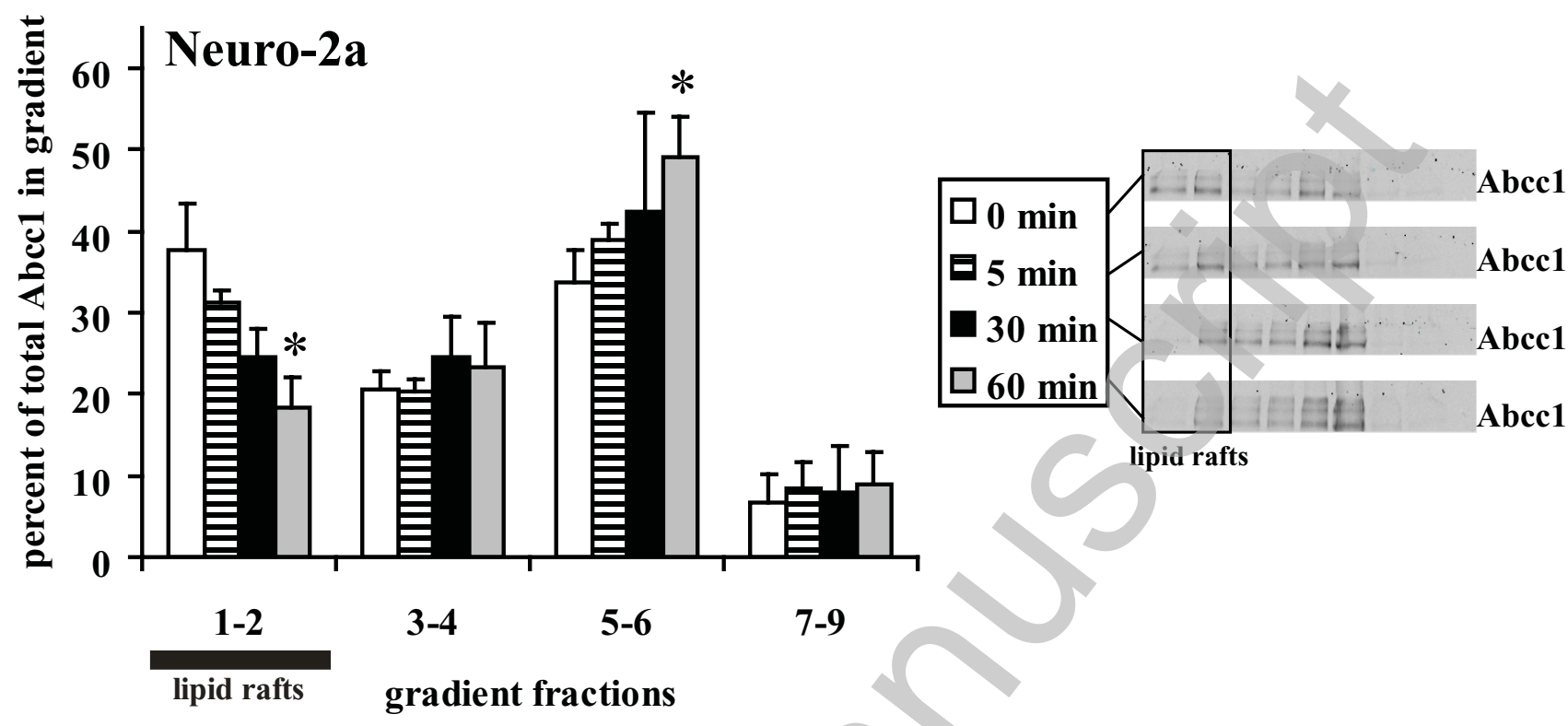

$\mathrm{B}$
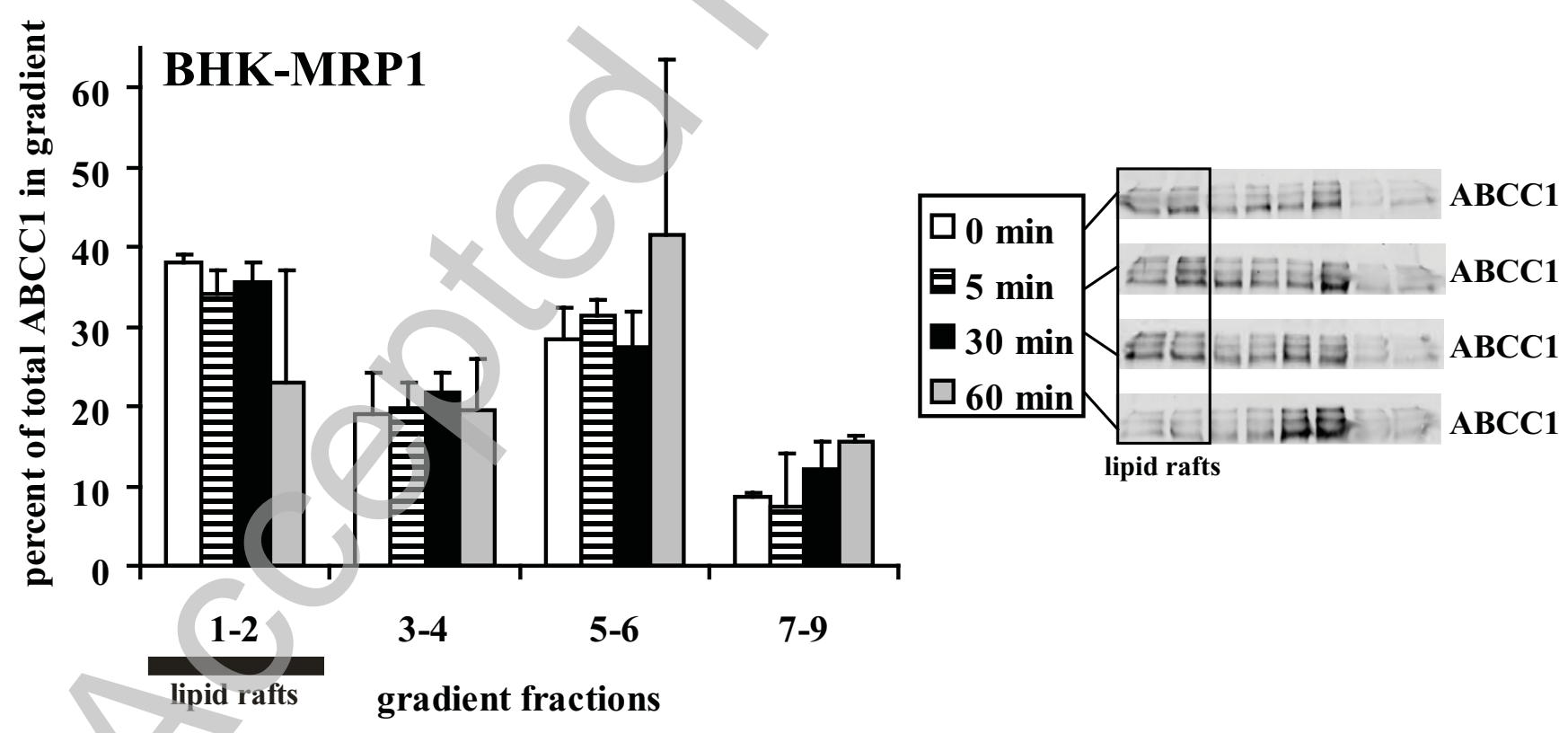

Figure 4 
A

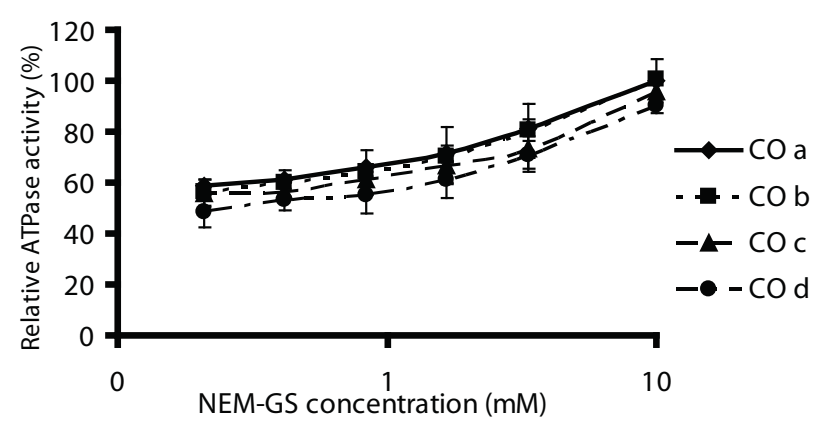

C

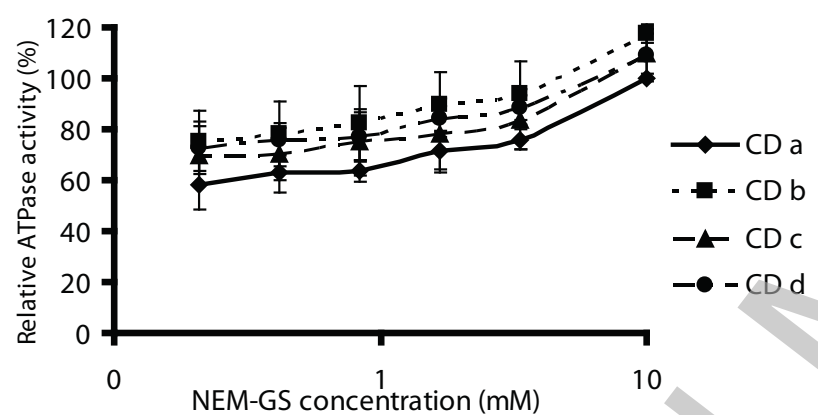

E

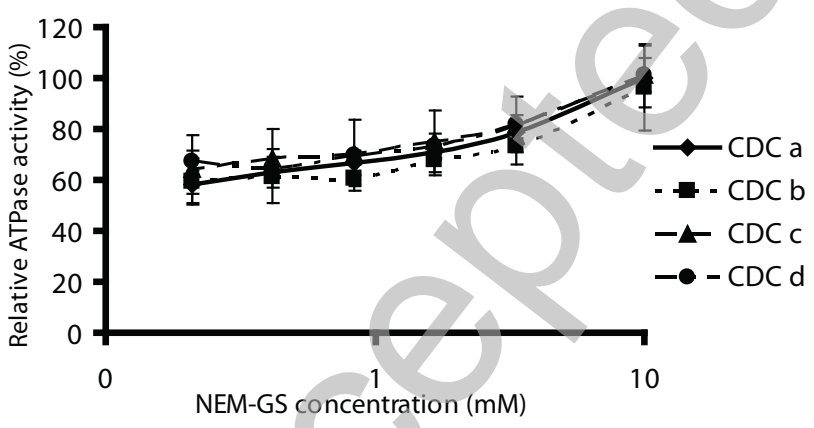

B

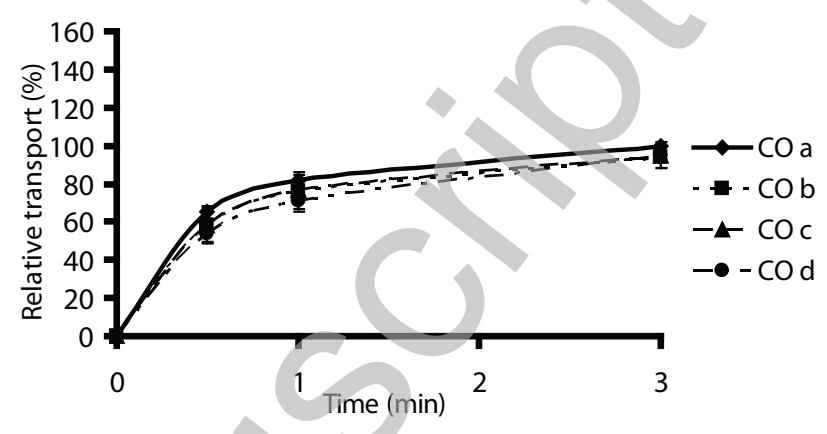

D

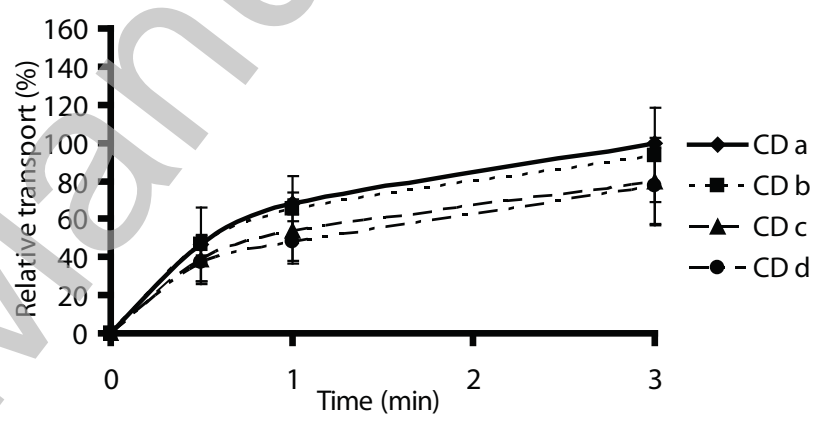

F

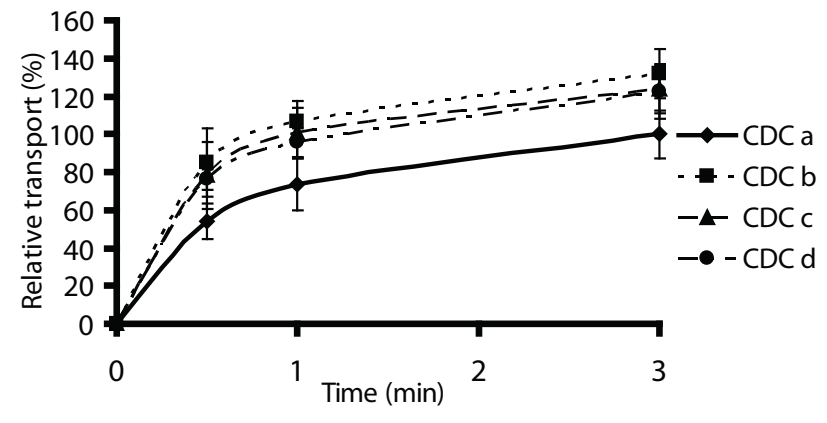

\section{Figure 5}

